CESIS Electronic Working Paper Series

Paper No. 420

\title{
Pre- and post-entrepreneurship labor mobility of entrepreneurs and employees in entrepreneurial firms
}

Kristina Nyström

August, 2015 


\title{
Pre- and post-entrepreneurship labor mobility of entrepreneurs and employees in entrepreneurial firms
}

\author{
Kristina Nyström \\ Centre of Excellence in Science \& Innovation Studies (CESIS), Department of Industrial Economics and \\ Management, Royal Institute of Technology (KTH), and The Ratio Institute.
}

kristina.nystrom@indek.kth.se

\begin{abstract}
This chapter provides a literature review of existing research and identifies research gaps related to the labor mobility of both entrepreneurs and employees in entrepreneurial firms. Regarding entrepreneurs, there is a lot of research on their individual characteristics, including prior experience, and how the individual characteristics and experiences influence the performance of the firm. However, less is known on the postentrepreneurship employment activity of entrepreneurs and how their prior experiences influence their future labor market careers.

Regarding the labor mobility of employees in entrepreneurial firms, there is an emerging stream of literature on the individual characteristics of these employees. However, many issues related to their prior experience remain unexplored. Furthermore, labor mobility after working with an entrepreneurial firm is relatively less explored at this point. Accordingly, this chapter intends to summarize current research and outline avenues for future research regarding a) pre-entrepreneurship labor mobility of entrepreneurs and b) postentrepreneurship labor mobility of entrepreneurs, as well as c) pre-entrepreneurship labor mobility of employees in entrepreneurial firms and d) post-entrepreneurship labor mobility of employees in entrepreneurial firms. In addition, the role of institutions and, in particular, employment protection laws (EPLs) for labor mobility of entrepreneurs and employees in entrepreneurial firms are discussed.
\end{abstract}

Keywords: entrepreneurship, labor mobility, employees in entrepreneurial firms

JEL codes: L26; J21; J62 


\section{Introduction}

In recent decades, the role of entrepreneurship for economic dynamics and economic growth has received a lot of attention from researchers and policymakers. Empirical studies show that, at least in the long-run, there a positive relationship between entrepreneurship, productivity and economic growth (see, e.g., reviews of the empirical literature by van Praag and Versloot (2007) and Nyström 2008a). How does productivity increase and generate growth through the creation of entrepreneurial ventures? One reason is that many new ventures are innovation-based. Hence, entrepreneurship is claimed to be an important link to commercialization of innovations (Acs, et al. 2009). Furthermore, entrepreneurship is an important part of the structural change process. Entrepreneurship induces re-allocation of resources and hence improves the efficiency of the utilization of resources (Schumpeter 1934 and 1942). Finally, labor mobility induced by the creation of new firms, may create knowledge spillovers. According to endogenous growth theories, interactions between individuals result in knowledge spillovers. These knowledge spillovers are claimed to stimulate innovation and productivity growth and therefore be important for economic growth (Romer 1986; 1990 and Lucas 1988). These knowledge spillovers are also expected to occur when individuals decide to start a new firm (see, e.g., Fornnahl, Zellner and Audretsch, 2005).

Every year, there is a quite substantial turbulence of firms and labor mobility in an economy. International evidence shows that annual entry and exit rates usually are about 5 to 10 percent (see e.g. Baldwin, 1995, Geroski, 1991, and Nyström 2006). However, international studies also identify substantial differences across industries and entry and exit rates are generally found to be higher in the service sectors compared to the manufacturing industry (see e.g. Dunne et al 1988 and Nyström 2007).

In which labor mobility flows do entrepreneurial activities result? When a new firm is established, this induces labor mobility for the entrepreneur, who may leave employment to try out a new opportunity as an entrepreneur. Furthermore, if the entrepreneurial venture expands beyond the founder of the company, additional employees need to be recruited to the firm, which also induces labor mobility. These new employees need to be recruited from other firms or among individuals currently outside the labor market. They can be recruited from already existing firms, from firms closing down their business, or among individuals that currently are entrepreneurs. Recruitment among individuals currently not employed in labor market may include recruitment of labor market entrants or individuals re-entering employment after a period of for example studies or unemployment. Hence, the establishment of the entrepreneurial venture induces labor mobility of both entrepreneurs and employees in entrepreneurial firms. This paper intends to provide a literature review of existing research related to the labor mobility of both entrepreneurs and employees in entrepreneurial ventures. Note that this literature review has no intention of being comprehensive, but rather aims at pointing to strands of literature covering the relevant 
aspects discussed. The chapter will also outline avenues for future research on this matter. I will focus on labor mobility related to both the period pre- and post-entrepreneurial activity as well as pre- and post-employment in an entrepreneurial firm. Hence, I will discuss a) preentrepreneurship labor mobility of entrepreneurs and b) post-entrepreneurship labor mobility of entrepreneurs, as well as c) pre-entrepreneurship labor mobility of employees in entrepreneurial firms and d) post- entrepreneurship labor mobility of employees in entrepreneurial firms. Furthermore because labor mobility of entrepreneurs and of employees in entrepreneurial firms are expected to be influenced by the institutional conditions in an economy, the role of institutions and, in particular, employment protection laws (EPLs), for labor mobility of entrepreneurs and employees in entrepreneurial firms will be discussed.

The paper is structured as follows: Section two discusses labor mobility pre- and postentrepreneurship. Section three discusses the recruitment process of employees in entrepreneurial firms and labor mobility pre- and post-employment in an entrepreneurial firm. Section four discusses how labor protection laws (EPLS) influence labor mobility of entrepreneurs and employees in entrepreneurial firms. Finally, in section five conclusions and some final remarks are provided.

\section{Labor mobility of entrepreneurs}

Labor mobility patterns prior and post entrepreneurship may exist in several paths. Figure 1 illustrates the possible labor mobility transitions pre- and post- the entrepreneur starting his or her venture. The labor market transitions illustrated in this figure will act as a way of structuring the discussion on the current state of the literature and identification of research gaps.

If we start looking at the period prior to the creation of a new entrepreneurial venture at a certain point in time, illustrated by the left side of the figure, the entrepreneur could leave his/her existing employment to become an entrepreneur, exit an existing entrepreneurial venture or enter/re-enter the labor market by, for example, leaving educational activities or returning to the labor market for other reasons. Post-entrepreneurial labor mobility options, illustrated by the right side of the figure, include that the entrepreneur may start a new entrepreneurial venture (i.e., serial entrepreneurship), take a job in an incumbent firm (which may be a new venture or an incumbent firm) or leave the labor market (for studies, unemployment or other reasons). 


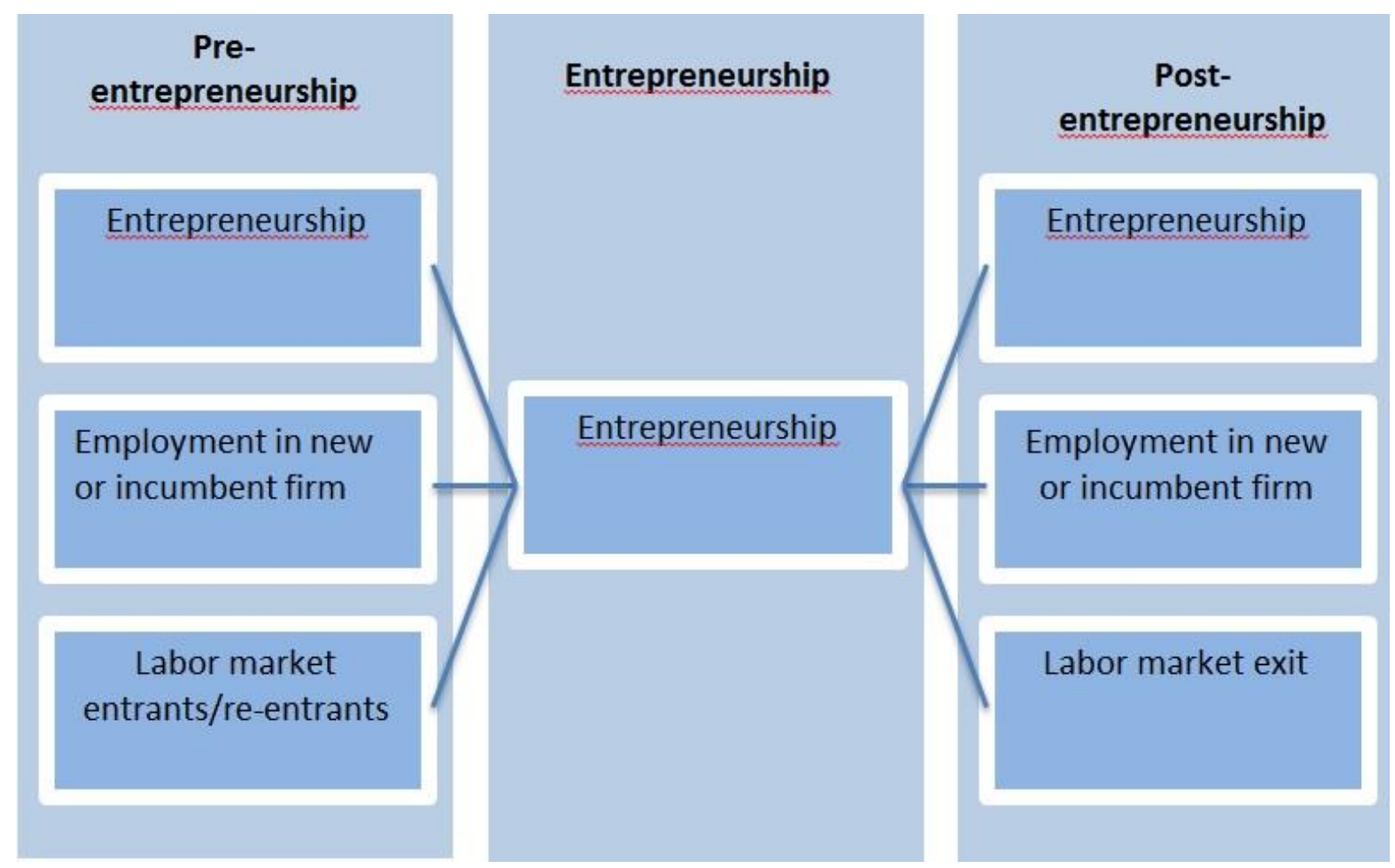

Figure 1: Labor mobility of entrepreneurs pre- and post-entrepreneurial activity.

\subsection{Pre-entrepreneurship labor mobility}

Starting with the literature on the period prior to the creation of a new entrepreneurial venture we can observe that during recent decades the literature on entrepreneurship has had a strong focus on individual characteristics, such as age, gender, education, and immigrant background, related to who becomes an entrepreneur. Furthermore, the literature has focused on how the individual characteristics of the entrepreneur influence the performance of the firm in terms of, for example, profitability, firm growth and survival (see, e.g., Parker, 2009 for a literature review). ${ }^{1}$

The literature on the determinants of entrepreneurship stresses the importance of human capital. One component of human capital is experience, which can be obtained through labor mobility prior to starting an entrepreneurial venture. Hence, we have knowledge about the pre-entrepreneurship employment activity of entrepreneurs with respect to how the entrepreneurs' prior experiences in the labor market may influence the propensity to become an entrepreneur and their subsequent performance as entrepreneurs. Human capital in terms of experience may, according to Shane (2003), include general business experience, functional experience, industry experience, start-up experience and vicarious

\footnotetext{
${ }^{1}$ In this paper, I focus on the entrepreneur as having an economic function, i.e., the entrepreneur as a risk taker, resource allocator or innovator (see, e.g., Glancey and McQuaid, 2000). It should be noted that other strands of the entrepreneurship literature have focused on entrepreneurs as persons with a certain form of behavior (see, e.g., Drucker, 1985) or persons with specific psychological traits (e.g., McClelland, 1961).
} 
experience. Functional experience refers to, for instance, experience in marketing or management. Vicarious experience refers to, for example, having observed a relative's or a friend's entrepreneurial activities. With regard to general business experience, previous research shows that many entrepreneurs find their ideas at their previous employers (Bhide, 2000), and those entrepreneurs that identified their business ideas at a previous employer tend to have higher growth rates (Dunkelberg et. al 1987). Furthermore, diversity of experience is tested by the "jack-of-all-trades" hypothesis, which implies, for example, that the number of different work roles and the number of different fields of experience are found to influence the probability to become an entrepreneur (Lazear, 2005, Wagner, 2003 and 2006). Furthermore, varied job experience is associated with greater entrepreneurial aspirations (Hyytinen and Ilmakunnas (2007a).

With regard to the performance indicator venture growth, having previous managerial experience seems more important than previous experience of entrepreneurship in the same sector (Storey, 1994). However, Hyytinen and Maliranta (2008) find that transition from employment to entrepreneurship is relatively rare. They also find that small firms spawn more new firms. However, we do not know about the reason for this difference or the reason for the individuals' transition to entrepreneurship. We do not know if these transitions are necessity or opportunity-based. Much of the literature on labor transitions between employment and self-employment has used individual-firm-level-based register data. The availability of this dataset gives us much detailed information about the individual and the firm. However, these datasets do not provide us with detailed information about whether the transition to entrepreneurship is necessity-based, for example, due to layoffs, or opportunity-based. Distinguishing between the different motives behind the transitions from employment to entrepreneurship would be interesting to explore further.

Regarding previous experience as entrepreneurs (serial entrepreneurship), previous empirical evidence suggests that individuals who have worked as entrepreneurs in the past and individuals with entrepreneurial aspirations are more likely to become entrepreneurs in the future (Hyytinen and IImakunnas 2007b). On the performance of serial entrepreneurs, Parker (2013) find that they obtain temporary benefits from entrepreneurship experience but that these benefits eventually disappear.

According to Figure 1 the third and last option of pre-entrepreneurial experience are entrepreneurs entering entrepreneurship as labor market entrants or re-entrants. There is quite extensive literature on the relationship between unemployment and entrepreneurship. Most of these evidences are on cross-section, time series or panel dimensions of this issue (see, e.g., Parker (2009) for a literature review). However, we can also find some interesting studies regarding the transitions from unemployment to entrepreneurship. Regarding the frequency of transitions to self-employment, Cowling and Taylor (2001) find that most of them transition into paid employment or remain unemployed. However, the unemployed are more likely to transition into self-employment 
compared to the employed (Evans and Leighton, 1990). In addition, it is found that a history of job changes increases the willingness to become an entrepreneur (van Praag and van Ophem (1995). What about the performance of ventures started by previously unemployed persons? Carrasco (1999) find that although unemployed people have a higher probability than employees to enter self-employment, their failure rate is higher. Andersson and Wadensjö, (2007) find that previous employees who become entrepreneurs are more successful as entrepreneurs compared with unemployed people that become entrepreneurs. However, few studies on the transitions to entrepreneurship focus on entrepreneurship as a way to enter the labor market. As previously mentioned, there are numerous studies on the role of age and entrepreneurship, using age as a proxy for experience. However, few, if any, of these studies are able to explicitly study labor market entrants. This would be particularly interesting due to the focus on young entrepreneurs among many policymakers. Interesting research questions would, for instance, be to study if entrepreneurship is a way to enter the labor market enhances or aggravate future career performance. How do employers perceive and value entrepreneurship as a way to enter the labor market?

To conclude this section we note that the prior experience of entrepreneurs as employees and serial entrepreneurs are relatively well explored in the literature. We also have empirical knowledge about the transition from unemployment to entrepreneurship. Hence, the link between labor market entrants and re-entrants is identified as less explored and should be interesting for further empirical research.

\subsection{Post-entrepreneurship labor mobility}

Looking at the labor mobility flows from entrepreneurship, (the right part of Figure 1) transitions may include entrepreneurship (serial entrepreneurship), employment or exiting the labor market. As previously mentioned, we have knowledge about serial entrepreneurs continuing entrepreneurial activity. Comparably less is known about the postentrepreneurial labor mobility to employment. Here, there are theoretical as well as empirical contributions to be made. Hence, knowledge about how the and experience of entrepreneurship is valued in a future career as employee would be interesting to examine. It can be hypothesized that the role of entrepreneurship experience in future labor market careers may depend on the strength of the individual's current position in the labor market. For some entrepreneurs with a weaker position in the labor market (such as immigrants), experience of entrepreneurship may be a way to signal to the labor market that he or she possesses capabilities and competences, which are attractive for employees. Hence for immigrant entrepreneurs, entrepreneurship may act as an entry port to regular employment. Furthermore, the value of entrepreneurial experience in the "regular" labor market would be interesting to study more extensively. Is experience of entrepreneurship a valuable resource in other positions in the labor market? Are persons with entrepreneurial experience perceived as more qualified to take on management positions? Do individuals 
with experience as entrepreneurs perform better or worse in terms of, for example, wage development or promotions compared with workers without entrepreneurial experience? There are a few studies on the effect of self-employment on wages. These studies generally find insignificant or negative effects of past self-employment on current wages. For instance Brucea and Schuetze (2004) find that returning to wage employment after brief spells of selfemployment do not increase earnings and probably rather decrease earnings. Kaiser and Malchow-Møller, (2011) find that, on average a spell of self-employment, is associated with lower wages in dependent employment. However, interestingly enough they find that this negative effect disappear and are even positive for self-employed who switch to dependent employment in the same sector as their self-employment. The effect also disappears for former self-employed earning a high income and for former self-employed hiring more than one employee. These results indicate that opportunity or necessity based transitions from self-employment to dependent wage employment may be influential for these results.

Regarding exit from entrepreneurship, illustrated by the third option of post-entrepreneurial transition possibilities in Figure 1, we know that many exits are voluntary, i.e., they are not due to reasons related to the poor performance of the company. For instance, Cueto and Mato (2006) find that almost 50 percent of reported exits are due to bankruptcy, while the rest of the exits are voluntary, i.e., induced by, for example, the individual wanting to take on other opportunities, such as transitions into the labor market. However, in many of the statistical sources used for empirical analysis, voluntary and involuntary exits are not distinguishable. For the further research mentioned above, it is possible that the value of entrepreneurship experience is dependent on whether the exits were triggered by the high or low performance of the prior entrepreneurial activity.

Hence, to conclude the section on post-entrepreneurial labor transitions we identify the transition and valuation of entrepreneurial experience in the "regular" labor market, as well as exit transitions, as links with great potential to explore further in empirical research.

\section{Labor mobility of employees in entrepreneurial firms}

In this section, I discuss labor mobility pre- and post-employment in an entrepreneurial firm. Figure 2 illustrates the possible labor mobility transitions pre- and post-employment in an entrepreneurial firm. Again, this figure will act as a starting point for the discussion on the current state of the literature and identification of research gaps. As illustrated by Figure 2 or employees who take a job in an entrepreneurial firm, labor mobility patterns prior to this employment may differ. The employee in the entrepreneurial firm may leave his/her existing employment for this employment, close his/her existing entrepreneurial venture to take employment with an entrepreneur or be a labor market entrant or re-entrant. Postentrepreneurial labor mobility options include that the entrepreneur starts a new entrepreneurial venture, takes a job in an incumbent firm (which may be a new venture or 
an incumbent firm) or leave the labor market. However, before more explicitly discussing these different transition paths, empirical evidence on the recruitment process in an entrepreneurial venture is discussed.

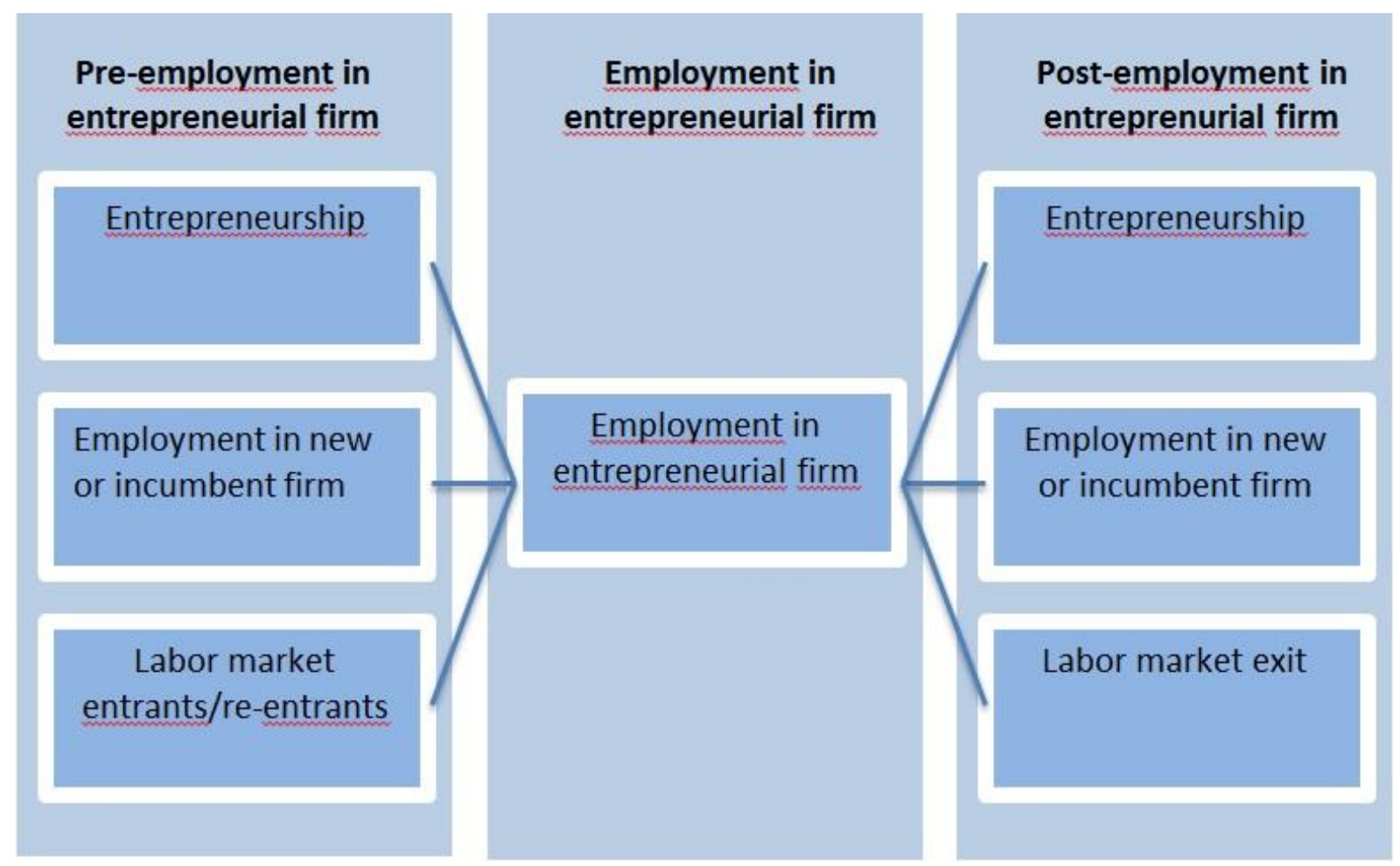

Figure 2: Labor mobility of employees pre- and post-employment in an entrepreneurial firm

When an entrepreneurial venture needs to recruit employees, a matching process is needed, where both the entrepreneurial venture and the potential employee must find a satisfactory match. However, according to Behrends (2007) and Williamson, Cable and Aldrich (2002), small and new firms have a competitive disadvantage in this recruitment process. Recruiting employees is difficult for entrepreneurial firms because they cannot rely on their reputation or market share to attract applicants (Aldrich 1999). Firms with a good reputation may attract more applicants, which implies that they have a larger pool of applicants to select from, which probably increases the quality of the staff hired (Turban and Cable, 2003). Additional disadvantages of entrepreneurial ventures in the recruitment process are that the mortality rate of entrepreneurial firms is high and that entrepreneurial firms often lack welldefined job descriptions, which may make them seem less legitimate and attractive to potential employees (Williamson 2000).

Entrepreneurial firms may also be unable to provide supplementary benefits, such as social security benefits or training (Tumasjan, Strobel and Welpe, 2011). These difficulties in the recruitment process imply that entrepreneurial ventures may have to rely more on social 
networks to obtain access to some resources required (see, e.g., Aldrich and Zimmer 1986; Greve and Salaff 2003). However, during the transition from the start-up phase to the growth phase of a company, recruitment efforts initially based on personal social networks change to business networks in order to facilitate diversity in competencies among employees (Leung et al. 2006). Alternatively, in recruiting employees using social networks, entrepreneurial firms have to a greater extent recruited their employees among individuals with weaker positions in the labor market, such as labor market entrants. While the exploitation of social networks in the entrepreneurial process is relatively well explored in the literature, the latter perspective is, as I will discuss later on in this paper, relatively unexplored.

\subsection{Pre-entrepreneurship labor mobility of employees}

Regarding the labor mobility of employees prior to employment in entrepreneurial firms, illustrated by the left part of Figure 2, there is an emerging stream of literature on the individual characteristics of employees (see, e.g., Nyström, 2011; Dahl and Klepper, 2008; Ouimet and Zarutskie, 2014). For instance, Nyström (2011) finds that new firms hire a larger share of employees with immigrant backgrounds and that the share of employees with postsecondary educations is lower among new firms compared with incumbent firms. Ouimet and Zarutskie (2014) find that young firms disproportionately hire young workers and in particular young firms with innovation potential. However, less is known about the employee's employment history prior to the employment in the new venture. Nyström (2011) shows that employees of entrepreneurial ventures have a higher probability of being outsiders in the labor market. Hence, interesting avenues for future research would include studying to what extent employees in entrepreneurial firms come from firms closing down or whether employees accepting employment in a new venture have higher labor mobility compared with employees in incumbent firms. It should be noted that many of the studies that currently exist in this area often are based on data from countries such as Denmark and Sweden, countries where access to employer-employee matched data have enabled researchers to start investigating the employment history of employees in entrepreneurial firms. Hence there is clearly an interest in conducting similar studies for additional countries were access to these employer-employee datasets can be provided.

Another strand of literature explores the wage differential payed by new and incumbent firms. It is often argued that entrepreneurial firms pay lower wages and provide worse fringe benefits (see e.g. Shane, 2009). However, since as previously mentioned, employees in new ventures tend to have a weaker position in the labor market, this wage differential can be partly explained by this selection mechanism (Nyström and Zhetibaeva Elvung (2014). However,, non-pecuniary factors influencing the decision to take an employment in an entrepreneurial firm may also be very important for the individuals decision to accept an employment. Empirical, evidence shows that the non-pecuniary factors important for the 
decision to become an entrepreneur include, for instance, greater independence and job satisfaction (Hyytinen et. al. 2013). However, the non-pecuniary factors associated with accepting an employment in an entrepreneurial firm remains relatively unexplored in the literature.

Other interesting avenues for future research to explore are the social network dimensions of hiring decisions in entrepreneurial firms. Quantitative studies based on large social network databases could provide further insights. In addition, further qualitative studies closely following recruitment processes in new ventures are of great interest. As previously mentioned, the recruitment processes of entrepreneurial firms are discussed in the literature. However, this strand of literature tends to focus on the entrepreneur's perspective. More research that remains to be done should study the motives and strategies of employees taking on employment in a new firm.

To conclude this section on pre-employment in entrepreneurial firms all transitions paths illustrated in the left side of figure 2 (previous employment in new or incumbent firms, entrepreneurship, and coming from outside of the labor market) seem relatively unexplored in particular using quantitative data such as employer-employee matched data. Another areas worth stressing as important for future research is the importance of non-pecuniary factors for the decision to take an employment in an entrepreneurial firm.

\subsection{Post-entrepreneurship labor mobility of employees}

In this section, I discuss labor mobility transitions post-employment in an entrepreneurial firm. Klepper (2001) notes that studies on employee start-ups are rare. Since this article by Klepper was published, there have been some interesting studies on entrepreneurial spawning. However, regarding the transitions of previous employees to entrepreneurial firms, I think there is still a research gap to be filled. This literature tends to focus on the characteristics of the firms that generate start-ups and the performance of the spawned companies. In addition, these studies tend to be focused on the high-tech sector. Regarding the strand of literature on spin-offs, which focuses on the characteristics of the firms that generate spin-offs, the literature shows that successful parent firms, in terms of product leadership, are characterized by higher spin-off rates. However, Anderson et. al. (2012) find that firms with persistently high R\&D activities tend to generate fewer spin-offs. This is explained by the observation that these employees may have a higher opportunity cost related to starting a firm on their own if the incumbent firm offers high wages and stable employment conditions. Furthermore, empirical evidence shows that spin-offs tend to outperform other start-ups with respect to survival rates, employment creation and growth performance (see, e.g., Klepper, 2001, Klepper and Thompson (2005)).

What, then, drives individuals to leave their current company to create a spin-off? According to Klepper and Sleeper (2005) and Klepper and Thompson (2010), an important driver of 
spin-off activity is disagreement in the firm about the potential of opportunities or incongruity between the firm's current product or service offered or strategy and other opportunities that the employees have identified. Because disagreements on the future path of the company can become more pronounced in connection to a firm being involved in merger and acquisition activities (M\&As), spin-off activities have shown to increase post M\&A (Klepper, 2007). In the previous section, I discussed the distinction between involuntary and voluntary exits. A similar distinction would be interesting to make for entrepreneurial activities spurred by M\&As and defined as spin-offs. A spin-off triggered by $M \& A$ activities can be induced by the fact that the new management of the company wants to outsource certain activities. Hence, the spin-off company may keep its primary customer base. Other entrepreneurial activities spawned from the company may be less voluntary and induced by the previously mentioned disagreement about future paths of the company or fear of being laid off in the aftermath of the M\&A activity. Hence, these entrepreneurial activities may be more necessity-based, which probably has an effect on the expected performance of these spin-offs.

Given the previously mentioned literature on entrepreneurial spawning, I think there is a clear and interesting research gap to be filled. In most cases, the above-mentioned literature does not regard the extent to which the employees can be regarded as part of the entrepreneurial team, even though he/she is an employee. Hence, I think it would be interesting to place an increased focus on the individuals involved in the entrepreneurial spawning process and the experiences they have learned by specifically working in entrepreneurial firms. It can be argued that working for an entrepreneur provides a person with skills and experiences that can be used if one wants to try out entrepreneurial activities oneself. In addition, working for a successful entrepreneur may convince someone that overall, entrepreneurship is a viable alternative to paid employment. (However, working for an unsuccessful entrepreneur may have the opposite effect). These arguments may be viable in both high-tech and low-tech industries.

A second option for the transition of employees of entrepreneurial firms is to take employment in another firm (the second option illustrated in the right part of Figure 2). This firm may again be an entrepreneurial firm or a firm with a more stable position in the market. Here, there is a clear research gap to be filled because the literature, to the best of my knowledge, does not explore the transition to paid employment after working in an entrepreneurial firm. Do individuals with experience working for an entrepreneurial firm performs better or worse in terms of, for example, wage development or promotion possibilities, compared with workers without experience working with an entrepreneurial firm?

Regarding the third option, the transition of employees which results in an exit from the labor market (illustrated by the last transition option in the right part of Figure 2), we have to consult the literature available on displacements if the individual face a situation where 
the firm closes down. As noted by Nyström and Viklund Ros (2014), much of this literature is focused on the characteristics of the individuals who are affected by displacements. According to this literature, older individuals, workers, women, less-educated workers and employees with long tenures are found to suffer most from displacement (see, for instance, OECD, 2013). Less is known about the extent to which the characteristics of the closed firm influence transitions to new employment and the future labor market performance of displaced workers. Do displaced workers from an entrepreneurial firm find it more or less difficult to transition to a new job compared with employees from large incumbent firms? It is possible that larger and incumbent firms are able to provide better support for their employees in this transition process. In addition, it may be the case that the closures of large incumbent firms receive more attention from policymakers which may induce additional policy measures aimed at reducing the problems associated with a large firm closure.

To conclude this section on post-employment in entrepreneurial firms, the transition to paid employment and valuation of this experience in the labor market is identified as an unexplored link. In addition, the labor market transition from employment in an entrepreneurial venture, in particular in the case of a firm closure needs further attention from researchers.

\section{Institutions and labor mobility of entrepreneurs and employees in entrepreneurial firms}

Institutions, defined as both the formal and informal rules of the game, (North, 1991; 1994) are very important in shaping which entrepreneurial activities take place in a society (Baumol 1990). Formal institutions include, for example, polity, judiciary and bureaucracy. Informal institutions include, for example, norms and customs. The literature on the relationship between institutions and entrepreneurship is now rather extensive (see, e.g., Boettke and Coyne (2009) for a literature review and Nyström (2008b), who shows a positive relationship between regulatory quality measured by the Economic Freedom of the World (EFW) index and self-employment). However, in this section, I will explicitly focus on the institutions that are particularly important for labor mobility and, in particular, employment protection legislation (EPL). From a theoretical perspective, one could expect strong EPLs to discourage entrepreneurial activities. The arguments for such a relationship is, first, that small (and new) firms are disproportionately burdened by EPLs. The argument here is that entrepreneurial firms have fewer possibilities to afford the costs of hiring and firing that EPLS impose. In addition, small and new firms are more vulnerable in cases of making lesssuccessful hiring decisions. Hence, it is argued that EPLs both discourage entrepreneurship and lower survival rates (Parker, 2009). On the other hand, as argued by Acharya et. al. (2013), EPLs provide employees with security in cases of the short-term failure of their activities. This security may make employees more inclined to become involved in innovative 
activities that have the potential to create value for the firm in the long run. Hence, EPLS may stimulate risky, but in the case of success, very profitable, activities, which may increase the chances of survival of the company.

For individuals employed in a firm, EPLs may also influence their decisions to become an entrepreneur. EPLs, which provide protection for employees with long tenure (such as those in Sweden), may make individuals less prone to trying out entrepreneurial activities. If they decide to leave a company to start a new firm, they will lose their tenure position in the firm, and if they return to positions as employees, they will be more exposed in the case of an economic downturn or in case the firm reduces its staff for other reasons. For policymakers, it is a difficult challenge to find the right balance between ensuring that sufficient labor mobility takes place at the same time as sufficient employment security for workers is provided.

Regarding the current empirical evidence on the relationship between entrepreneurship and EPLs, the evidence is mixed. Among the studies that find a negative relationship between entrepreneurship and EPLs, the studies by Kanniainen and Vesala (2005), Klapper et al (2006) and van Stel et al (2007) can be mentioned. However, there are also a number studies, such as Robson (2003) and Ciccone and Papioannou (2007), finding insignificant statistical results for this relationship. Related to EPLs and firm-level performance, Bassanini et al. (2009) find that dismissal regulations decrease total factor productivity (TFP). Conversely, Acharya et al. (2013) find that more stringent dismissal laws increase participation in innovative activities among employees, particularly those in innovationintensive industries. Why do we have these ambiguous empirical results? As Parker (2009) notes, most of the previously mentioned evidence is based on cross-country data. In order to better understand the relationship between EPLs, future studies should use less aggregate data. Furthermore, it would be interesting to more explicitly evaluate the consequences of changes in EPL schemes in individual countries and the effect on labor mobility and entrepreneurship. Furthermore, the empirical evidence mentioned above is related to entrepreneurship in general and does not study the transitions to entrepreneurship and transitions to employment in entrepreneurial firms. An interesting research question to study would be if entrepreneurs in countries with more or less relaxed EPLs find that it is easier to recruit experienced workers compared with entrepreneurs in countries with stricter EPLs.

\section{Summary and concluding remarks}

This paper has provided a literature review of existing research and identified research gaps related to the labor mobility of both entrepreneurs and employees in new firms before and after their activities as entrepreneurs or employees in entrepreneurial firms. Regarding the pre-entrepreneurship experience of entrepreneurs, the link between labor market entrants and re-entrants was identified as the least-explored link. Regarding post-entrepreneurship 
transitions, exit transitions from the labor market as well as the transitions and valuation of entrepreneurial experience in the "regular" labor market were identified as areas with research gaps interesting to explore further. In particular, it could be interesting to try to distinguish between voluntary and involuntary transitions. Regarding the valuation of entrepreneurial experience in the labor market it should be possible using employeremployee match data to study wage differentials between employees with and without entrepreneurial experience. Qualitative studies conducting interviews with persons responsible for recruitment of employees could also shed further light into how entrepreneurial experience is valued on the labor market.

Regarding pre-employment with an entrepreneurial firm, all transitions paths (previous employment, entrepreneurship, and paths coming from outside of the labor market) seem relatively unexplored using quantitative data, even though there is currently an emerging quantitative literature stream exploring who new firms employ (e.g., Nyström 2011; Dahl and Klepper 2008). The empirical findings so far in this strand of literature indicate that entrepreneurial ventures seem important for labor market dynamics, in particular related to the employment of individuals with a weaker position in the labor market. Further empirical studies in this area would also include studies on to what extent different types of entrepreneurial ventures are able to attract different types of employees and to what extent this influence firm performance. Such studies would, for instance, include distinguishing between high-tech start-ups and low-tech start-ups, spin-offs versus non-spin offs, academic spin-offs vs non-academic spin-offs or large firm spin-offs, versus small firm spin-offs. Finally, extending on the literature on wage differentials between new and incumbent would include the study of the non-pecuniary benefits associated with an employment in anew firm.

For post-employment in an entrepreneurial firm, the transition to entrepreneurial activity is relatively well explored in the entrepreneurial spawning and spin-off literature. However, the transition to paid employment was identified as an unexplored research area. Interesting research questions would, for example, be related to how employment with an entrepreneurial firm is valued in the labor market. Here both quantitative and qualitative studies in a similar vein as mentioned above regarding the valuation of entrepreneurial experience should be of interest. In addition, given that employment in a new firm is very risky because mortality is high, it would be interesting to explore the future labor market performance of individuals displaced from an entrepreneurial firm.

Finally, in this paper the role of EPLs for the labor mobility of entrepreneurs and employees in entrepreneurial firms was discussed. Here, more empirical research based on micro-level data might be able to shed additional light on the currently relatively ambiguous empirical results on the relationship between EPLs and entrepreneurship. 


\section{References:}

Acharya, V. V., Baghai, R. P. and Subramanian, K. V. (2013), "Labor laws and innovation", Journal of Law and Economics, Vol. 56, . 4: 997-1037.

Acs, Z.J. D. B. Audretsch, P. Braunerhjelm and B. Carlsson, (2009), "The knowledge spillover theory of entrepreneurship", Small Business Economics, Vol. 32, 1: 15-30.

Aldrich H. and Zimmer C. (1986), "Entrepreneurship through Social Networks", In Sexton, D and R Smiler (eds.) , The Art and Science of Entrepreneurship Ballinger, New York p 3-23

Andersson, M. Baltzopoulos, A. and Lööf H., (2012), "R\&D strategies and entrepreneurial spawning", Research Policy, Vol. 41, 54-68.

Andersson, P. and E. Wadensjö, (2007), "Do the unemployed become successful entrepreneurs?" International Journal of Manpower, Vol. 28, 7:604-26.

Baldwin, J. R. (1995) The Dynamics of Industrial Competition: A North American Perspective, Cambridge University Press.

Bassanini, A., Nunziata, L. and Venn, D. (2009), Job protection legislation and productivity growth in OECD countries, Economic Policy, Vol. 24 58: 349-402.

Baumol W. J., (1990), “Entrepreneurship: Productive, Unproductive and Destructive”, Journal of Political Economy, Vol. 98, 5:893-921.

Behrends T. (2007), "Recruitment practices in small and medium size enterprises. An empirical study among knowledge-intensive professional service firms", Management Revue 18:55-74

Bhide A. V. (2000), The Origin and Evolution of New Businesses, Oxford University Press.

Boettke P. and Coyne C. (2009), "Context Matters: Institutions and Entrepreneurship" Foundations and Trends in Entrepreneurship, Vol. 5, 3:135-209.

Brucea D. and H. J. Schuetze, (2004), “The labor market consequences of experience in selfemployment”, Labour Economics, 11 (2004) 575-598

Carrasco, R. (1999) "Transitions to and from self-employment in Spain: an empirical analysis", Oxford Bulletin of Economics and Statistics, 61, 315-41.

Ciccone A. and E Papaioannou (2007), "Red Tape and Delayed Entry", Journal of the European Economic Association, Vol. 5, 2-3:444-58

Cowling M. and M. Taylor, (2001) "Entrepreneurial women and men: two different species?" Small Business Economics, Vol. 16 167-75 
Cueto B. and J. Mato (2006) "An analysis of self-employment subsidies with duration Models", Applied Economics, Vol. 38, 23-32

Dahl, M. S. and S. Klepper, (2008) Whom Do New Firms Hire? (September 8, 2008). Available at SSRN: $\underline{\text { http://ssrn.com/abstract=2420122 }}$

Drucker, P. E (1985) Entrepreneurship and Innovation, Heinemann, London.

Dunkelberg W. Cooper, A. C. Woo, C. and Denis W. (1987) "New firm growth and performance" in: N. Churchill et. Al. (eds) Frontiers of Entrepreneurship Research, Babson College pp. 307-21.

Dunne, T. M. J Roberts, and L Samuelson, (1988) Patterns of Firm Entry and Exit in U.S Manufacturing industry, Rand Journal of Economics, 19, 4:495-515

Evans D. S. and L- S. Leighton, (1990), "Small business formation by unemployed and employed workers", Small Business Economics, Vol. 2, 319-30.

Fornahl, D. Zellner C \& Audretsch D. B (2005) The Role of Labour Mobility and Informal Networks for Knowledge Transfer, Springer, Berlin

Geroski, P. (1991) Market Dynamics and Entry, Blackwell, Oxford

Glancey K. S and R. W. McQuaid, (2000) Entrepreneurial Economics, Palgrave, New York.

Greve A. and Salaff J. W. (2003). "Social networks and Entrepreneurship", Entrepreneurship Theory and Practice, Vol. 28, 1:1-22.

Hyytinen A. and P. Ilmakunnas (2007), Entrepreneurial aspirations another form of job search? Small Business Economics, Vol. 29, 63-80

Hyytinen A. and P. Ilmakunnas (2007), "What distinguishes a serial entrepreneur?" Industrial and Corporate Change, Vol. 16. 5:793-821.

Hyytinen A. and Maliranta M. (2008) "When do employees leave their job for entrepreneurship?" Scandinavian Journal of Economics, Vol. 110, 1:1-21.

Hyytinen A. ,P.Ilmakunnas and O. Toivanen (2013), The return-to-entrepreneurship puzzle, Labour Economics, 20 57-67.

Kaiser K and N. Malchow-Møller, (2011), Is self-employment really a bad experience? The effects of previous self-employment on subsequent wage-employment wages, Journal of Business Venturing, 26 572-588.

Kanniainen, V and Vesala, T. (2005) "Entrepreneurship and labour market institutions", Economic Modelling, 22 828-47. 
Klapper, L, L Laeven and R. Rajan, (2006), "Entry Regulation as a Barrier to Entrepreneurship", Journal of Financial Economics, Vol. 82, 3:591-629.

Klepper, S., 2001. "Employee startups in high-tech industries. Industrial and Corporate Change", Vol. 10, 639-674.

Klepper, S. (2007) "Disagreements spin-offs and the evolution of Detroit as the capital of the U.S. Automobile Industry, Management Science, Vol. 53 4:616-631.

Klepper S. and Sleeper S (2005) "Entry by Spinoffs", Management Science, Vol. 51 8:12911306.

Klepper S. and Thompson P. (2005) Spinoff entry in high tech industries motives and consequences, Florida International University, Florida.

Klepper S. and Thompson P. (2010) "Disagreements and intra industry spin-offs", International Journal of Industrial Organization, Vol. 28, 5:526-538.

Leung, A. Zhang J. Wong P K and M D Foo, (2006) "The use of Networks in human resource acquisition for entrepreneurial firms: Multiple "fit" considerations", Journal of Business Venturing, Vol. 21, 664-686.

Lucas, R. E. (1988) "On the mechanisms of Economic Development", Journal of Monetary Economics, Vol. 22, 3-42.

McClelland, D. C. The Achieving Society, Van Nostrand, Princeton New Jersey.

North, D. (1991), "Institutions", Journal of Economic Perspectives, Vol. 5, 1:97-112.

North, D. (1994), "Economic Performance through Time", American Economic Review, Vol. 84, 3:359-68.

Nyström, K. (2006) Entry and Exit in Swedish Industrial Sectors, JIBS Dissertation series No 32, Jönköping International Business School, Jönköping, Sweden

Nyström, K. (2007) "Patterns and Determinants of Entry and Exit in Industrial Sectors in Sweden", Journal of International Entrepreneurship", Journal of International Entrepreneurship, Vol 5, (3-4) 85-110.

Nyström , K. (2008a) "Is Entrepreneurship the Salvation for Enhanced Economic Growth? in Columbus F. Entrepreneurship and its Economic Significance, Behavior and Effects, Nova Science.

Nyström, K. (2008b), "The Institutions of Economic Freedom and Entrepreneurship: Evidence from Panel Data", Public Choice, Vol. 136, 3-4:269-282.

Nyström, K. (2011) "Labor mobility and entrepreneurship: Who do new firms employ?", CESIS Electronic Working Paper Series, Working Paper 250. 
Nyström K. and I. Viklund Ros. (2014) Exploring regional differences in the regional capacity to absorb displacements Ratio Working Paper No. 235. Ratio, Stockholm

Nyström K. and G. Zhetibaeva Elvung (2014) New firms and labor market entrants: Is there a wage penalty for employment in new firms? Small Business Economics, 43, 2:399-410.

Ouimet, P. and Zarutskie R. (2014) Who works for startups? The relation between firm age, employee age, and growth, Journal of Financial Economics, 112 386-407

OECD (2013) OECD Employment Outlook 2013, OECD,

Paris.http://www.keepeek.com/Digital-Asset-Management/oecd/employment/oecdemployment-outlook-2013 empl_outlook-2013-en\#page214 Retrieved 2015-02-05

Parker, S. (2009) The Economics of Entrepreneurship, Cambridge University Press.

Parker, S (2013) Do serial entrepreneurs run successively better-performing businesses? Journal of Business Venturing 28 652-666

Robson M. T. (2003) "Do stricter employment protection legislation promote selfemployment?" Small Business Economics, Vol. 21 309-319.

Romer, P. M. (1990) "Endogenous Technological Change", Journal of Political Economy, Vol Vol. 98 5: 71-102.

Romer, P. M. (1986) "Increasing Returns and Long-run Growth", Journal of Political Economy, Vol. 94 5:1002-37.

Shane, S. (2003) A general Theory of Entrepreneurship : The Individual-Opportunity Nexus. Edward Elgar, Cheltenham

Shane, S. (2009). Why encouraging more people to become entrepreneurs is bad public policy. Small Business Economics, 33, 141-149.

Schumpeter, J. (1934) The Theory of Economic Development, Harvard University Press, Cambridge Massachusetts.

Schumpeter, J. (1942) Capitalism, Socialism and Democracy, Harper and Row, New York

Storey, D. J (1994) Understanding the Small Business Sector, Routledge, London.

Tumasjan, A, Strobel M. and Welpe, I M., (2011) "Employer Brand Building for Start-Ups: Which Job Attributes Do Employees Value Most?" (Zeitschrift für Betriebswirtschaft, Vol. 81, 111-136.

Turban, D. B and Cable D. M. (2003) "Firm Reputation and Applicant Pool Characteristics", Journal of Organizational Behavior, Vol. 24, 733-751 733-751 
van Praag, M.C. and P.H. Versloot (2007), "What is the Value of Entrepreneurship? A Review of Recent Research", Small Business Economics, Vol. 29, 4:351-382.

van Praag, M. C. and H. van Ophem, (1995) "Determinants of willingness and opportunity to start as an entrepreneur", Kyklos, Vol. 48, 513-40.

van Stel, A. D J. Storey and A. R Thurik, (2007), "The Effect of Business Regulation on Nascent and Young Business Entrepreneurship" Small Business Economics, Vol. 24, 311-21.

Wagner J. (2003) "Testing Lazear's jack -of -all-trades view of entrepreneurship with German microdata", Applied Economics Letters, Vol. 10, 687-89.

Wagner J. (2006) "Are nascent entrepreneurs jack of all trades? A test of Lazear's theory of entrepreneurship with German data", Applied Economics, Vol. 38, 2415-19.

Williamson I O (2000) "Employer legitimacy and recruitment success in small businesses". Entrepreneurship Theory Practice, Vol. 25, 27-42

Williamson I O, Cable DM, Aldrich HE (2002) Smaller but not necessarily weaker: how small businesses can overcome barriers to recruitment. In: Katz J, Lumpkin, T (Eds), Managing People in Entrepreneurial Organizations (Advances in Entrepreneurship, Firm Emergence 